\title{
Nemuno stacionariems hidrometriniams tyrimams 200 metur
}

Jonas Jablonskis,

\section{Mykolas Lasinskas}

Lietuvos mokslu akademijos

Vandens problemu taryba,

Hidrologijos laboratorija,

Lietuvos energetikos institutas,

Breslaujos g. 3, LT-44403 Kaunas

El.paštas: hydro@mail.lei.lt 2010-aisiais sukako 200 metų, kai Nemune pradèti nuolatiniai hidrometriniai darbai. Sèliuose, Nemuno deltos atšakoje Rusneje, $35 \mathrm{~km}$ nuo žiočių, $1810 \mathrm{~m}$. liepos $26 \mathrm{~d}$. ịsteigta (pradèti nuolatiniai matavimai ir stebejimai) pirmoji Nemuno baseine vandens matavimo stotis (VMS). $1810 \mathrm{~m}$. rugsèjo $22 \mathrm{~d}$. Atmatos atšakoje įrengta antroji, Rusnès VMS (13 km nuo žiočių), 1811 m. sausio 1 d. - trečioji Nemune, Tilžès VMS (59 km nuo žiočių). $1811 \mathrm{~m}$. spalio $1 \mathrm{~d}$. Nemune, Prūsijos-Rusijos pasienyje (111 km nuo žiočių) įsteigta dabar pagarsejjusi Smalininkų vandens matavimo stotis. Jos 200 metų ịsteigimo ir veiklos jubiliejaus sulauksime $2011 \mathrm{~m}$. spalio $1 \mathrm{~d}$.VMS įsteigimo tikslas, kaip nurodoma $1810 \mathrm{~m}$. vasario $13 \mathrm{~d}$. Prūsijos karaliaus vardu išleistoje instrukcijoje, buvo observuoti vandens horizontus, „be kurių negalima tikrai atlikti jokių hidrotechninių ịrengimų nei upių melioracijų“. Išskyrus Sẻlių VMS, kuri 1938 m. uždaryta, pirmosios VMS tebeveikia.

Smalininkų VMS pasauliui tapo žinoma ne tik dèl vandens lygio, ledo reiškinių režimo, bet ir dèl turimų nuotèkio duomenų unikalumo. Tokias ilgas moksliškai pagrịstas ir viešai paskelbtas hidrometrinių duomenų eiles turi tik viena kita upe pasaulyje. Tvarkant, analizuojant ir skelbiant šios stoties hidrometrinius duomenis daug pasidarbavo žymus hidrologas Steponas Kolupaila. Nemunas pagarsèjo pasaulyje, kai S. Kolupaila 1930 m. paskelbė 1812-1929 hidrologinių metų Smalininkų VMS vandens lygių bei ledo reiškinių duomenis, o 1933 m. IV Baltijos šalių hidrologų konferencijoje pateikè ir paskelbè 18121932 m. šios VMS nuotèkio duomenis ir pelnè žymių hidrologų palaikymą.

Straipsnyje nagrinejjamas Nemuno ties Smalininkais 1812-2009 metų, t. y. beveik dviejų šimtmečiu, nuotèkis, aptariama, kokios sąlygos stimuliavo Nemuno hidrometrinị tyrimą, analizuojamas duomenų patikimumas, nuotèkio režimas ir kaita per minètą laikotarpị.

Raktažodžiai: Nemunas, vandens matavimo stotis, upès vandens lygis, upių nuotèis, nuotèkio kaita

\section{IVADAS}

Nemunas turëjo ir turi didžiulę reikšmę šalies ekonomikai, kultūrai, net gamtos mokslui. Jo vandens ištekliai, pati upé, vandens tẻkmẻ buvo plačiai naudojama pagal laikotarpio poreikius ir susiklosčiusias galimybes. Poreikiai augo su technine pažanga, galimybès - su politine ekonomine situacija.

Nemunas be galo vertingas visais požiūriais kaip gamtos reiškinys. Mes šiuo straipsniu norime atkreipti skaitytojų dèmesi i tai, kad 2010 m. sukako 200 metų, kai Nemunas akylai kasdien stebimas: matuojamas vandens lygis, stebimi ledo reiškiniai, apskaičiuojamas upe tekančio vandens kiekis ir kiti jo hidrologiniai rodikliai. Svarbu ne tai, kad Nemunas, kaip ir dešimtys kitų šalies upių, kruopščiai tiriamas, tačiau jo hidrometriniai duomenys unikalūs tuo, kad jie yra vientisiniai ir apima du šimtmečius. Tokiais ilgalaikiais hidrometriniais duomenimis pasižymi vos kelios pasaulio upès (Nilas, Tibras, Elbė, Reinas, Dniepras ir kt.). Todėl galime analizuoti, kaip per šiuos šimtmečius tekèjo upè, kito jos vandeningumas. Šiame straipsnyje norime paliesti tris klausimus: kokios sąlygos lèmé Nemuno hidrometrinị tyrimą, kaip vertinami išmatuoti ir apskaičiuoti duomenys tikslumo požiūriu ir kaip jie atspindi šalies ir viso Baltijos regiono klimatinę būseną, pasiremiant teiginiu, jog upès (upių hidrologinis režimas) yra klimato produktas. 


\section{KODĖL BUVO TIRIAMAS NEMUNAS?}

I tai galima atsakyti trumpai - to reikalavo laikotarpis. Laivybai pakako upés vagos aprašymo, kelių tiesimui - upés vandens lygių, vandens ūkiui ir hidroenergetikai - upe pratekančio vandens kiekio.

Nemunas $937 \mathrm{~km}$ ilgio kelių valstybių teritorija tekanti upè, nuo ištakų $475 \mathrm{~km}$ teka Baltarusijos teritorija, $359 \mathrm{~km}$ - per Lietuvą, $116 \mathrm{~km}$ - valstybinemis sienomis su Baltarusija ir Kaliningrado sritimi [1]. Nemuno žemupys, kuris prasideda ittekèjus Neriai, turi deltą. Žemiau Tilžès (Sovetsko), $48 \mathrm{~km}$ nuo žiočiu atsiskiria kairioji Nemuno atšaka - Gilija (Matrosovka). Toliau Nemunas vadinamas Rusne. Ši vèl (13 km nuo žiočių) šakojasi ị kairiają atšaką - Skirvytę (Severnają) ir dešiniąją - Atmatą, kurios žiotys laikomos Nemuno žiotimis Kuršių mariose. Taigi Nemunas žinomas Chron po, Memel, Niomanec, Nioman, Neman, Rusnè ir Atmata vardais. Nemuno baseino plotas iki deltos $91813 \mathrm{~km}^{2}$, o su delta $-97864 \mathrm{~km}^{2}$, apima $72 \%$ Lietuvos teritorijos ir juo nuteka $85 \%$ šalies upių nuotèkio.

Nemuno baseino ir pačios upès priklausomybè glaudžiai siejasi su mūsų šalies istorijos vingiais. Nemunas, išskyrus dali žemupio, iki Liublino unijos (1569 m.) priklausè Lietuvos Didžiajai Kunigaikštystei, o po unijos - Abiejų Tautų Respublikai (ATR). Nemuno žemupys buvo kovų su Vokiečių ordinu arena.

Vokiečių ordinas 1231-1257 m. užvaldè visas prūsų žemes. Nemuno žemupio užkariavimas prasidèjo $1252 \mathrm{~m}$., kai prie Danès upès ir Klaipèdos sąsiaurio Livonijos ordinas užgrobė Klaipèdos gyvenvietę ir čia pastatè Memelburgo pili, iš kurios puldinèjo baltų žemes. Kuršiai ir sembai šio svarbaus strateginio punkto neapgynė. Taip buvo užgrobtas Nemuno žemupys, atkertant gyventojų susisiekimą su Baltijos jūros pakrante, kur prekiauta su atplaukiančiais ịvairių kraštų pirkliais.

Apie pilị išaugo Klaipėdos miestas, vokiškai Memel (kaip ir Nemunas - Memel), kuris tapo svarbiausiu Prūsijos karalystès uostu. Nepaisant to, kad Žalgirio mūšis susilpnino Vokiečių ordino agresiją, tačiau pagal $1422 \mathrm{~m}$. Melno taikos sutarties sąlygas Nemuno žiotys ir Klaipedda liko Ordinui, mat jis galutinai atsisake pretenzijų i Žemaitiją ir Užnemunę, bet jam liko Klaipedos kraštas. Lietuva neteko išejimo Nemunu prie Baltijos, kurios liko tik pakrante tarp Palangos ir Šventosios. Tik po kelių šimtų metų pagal 1919 m. Versalio sutartị Mažosios Lietuvos šiaurinè dalis - Klaipèdos kraštas buvo atskirtas nuo Vokietijos, o po pavykusio $1923 \mathrm{~m}$. Klaipedos krašto sukilimo tapo Lietuvos dalimi, tačiau 1939 m. fašistinè Vokietija ultimatyvia forma atėmè Klaipèdos kraštą, kuris po Antrojo pasaulinio karo vèl Lietuvos sudètyje. Politiniai ịvykiai paliete ir visą kitą Nemuno dalį. Po $1795 \mathrm{~m}$. III ATR padalijimo dešinysis Nemuno krantas nuo Gardino iki Smalininkų atiteko Rusijai, o kairysis - Prūsijai. Matyti, kad Nemunas, kartu su Lietuva, išgyveno labai skaudžias politines krizes.

Apie Nemuną turime ịvairiausių žinių, net nuo antikos laikų, kai minimas pats Nemunas (Chron po) ir juo arba palei ji èjęs vadinamasis Gintaro kelias, kuriuo nuo Baltijos krantų
Nemunu, Dniepru ir kitomis upemis gintaras buvo gabenamas ị Viduržemio jūros šalis [2]. Archeologiniai duomenys rodo, kad mūsų protèviai pirmiausia ịsikurdavo prie upių ir ežerų. Taip jiems buvo patogiau keliauti miškais apaugusiu kraštu, apsirūpinti maistu ir apsiginti nuo priešų.

Turimomis žiniomis vandens keliai Nemunu ir kitomis upėmis pagal išgales buvo prižiūrimi ir tobulinami. Nemuno vidurupio rèvos kliudè laivybai, todèl jau XIV a. bandyta šalinti iš jų akmenis. Pagal 1323 m. Gedimino sutartị su Švedijos, Anglijos ir Hanzos pirkliais bei 1342 m. Kęstučio sutartị su Anglija buvo vykdomi Nemuno reguliavimo darbai [3]. XIV-XVI a. istatymais buvo leista laisvai plaukioti visomis laivybinėmis upèmis, uždrausta jas tvenkti. Žinomas faktas, kai XIV a. Mikalojui Tarlai už akmenų pašalinimą iš upès vagos žemiau Gardino dèkingi miesto piliečiai Nemuno krante pastatė paminklą, o poetas A. Šreteris jam paskyré eiles.

Nemunas nuo neatmenamų laikų buvo prekybinis kelias, ypač viduramžiais, buvo siekiama, tobulinant laivybą, geriau ji pažinti. Hidrografiniu požiūriu šiems darbams labai talkino K. Radvilos parengtas ir $1613 \mathrm{~m}$. Amsterdame atspausdintas M 1 : 1290000 LDK žemèlapis. Tais laikais tai buvo tikslus žemèlapis, ir jis buvo naudojamas ilgą laiką. Jis pravertè 1765$1768 \mathrm{~m}$. įrengiant Oginskio kanalą, kuriuo buvo sujungtas laivuojamas Nemunas su Dniepru, 1824-1830 m. kasant Ventos-Dubysos kanalą, $1839 \mathrm{~m}$. kasant Augustavo kanalą ir kt.

Laivybai ir sieliams plukdyti Lietuvoje buvo naudojamos ir kitos upès: Neris, Šventoji, Nevėžis, Dubysa, Šešupe ir t. t. Svarbiausias prekybos centras prie Nemuno buvo Kaunas, o prekiu eksporto centrai - Gdansko, Karaliaučiaus ir Klaipédos uostai. Gyva prekyba čia vyko iki Pirmojo pasaulinio karo. Iš statistikos šaltinių [4] sužinome, kad Nemunu 18481857 m. praplaukè 23626 laivai ir 9800 sielių, Nerimi 18531856 m. - 385 laivai ir 555 sieliai. Suduždavo 1 iš 200 laivų. Iš Gardino ị Kauną laivai plaukdavo 3-4 dienas, o atgal žmonių tempiami laivai plaukdavo 20-30 dienų. 1829 m. nuotaikingą kelionę vytine iš Kauno ị Karaliaučių aprašè V. Sirokomlè [5]. Garlaiviai Nemunu pradèjo plaukioti $1854 \mathrm{~m}$. Nepriklausoma Lietuva disponavo penkiais įvairiu laiku įrengtais Nemuno uostais: Kauno (1919 m.), Kalnènu (1891 m.), Jurbarko (1937 m.), Smalininkų (1887 m.) ir Uostadvario (1917 m.). Statistikos duomenimis, ị didžiausią iš jų - Kauno uostą $1934 \mathrm{~m}$. atplauke 2285 garlaiviai ir 260 baržų, išplauke atitinkamai 2280 ir 308, atgabenę atitinkamai 2,7 ir 20,3 ir išvežę 3,0 ir 12,5 tūkst. t krovinių. Be to, Nemunu i Vokietiją sieliais buvo nuplukdyta apie 98 tūkst. kietmetrių miško medžiagos. Dabar laivyba Nemune labai menka.

Inžineriniai Nemuno tyrinėjimai atliekami nuo XIX a. pradžios. Po III ATR padalijimo $1803 \mathrm{~m}$. Prūsija ir Rusija susitare ištirti ir sureguliuoti jų užgrobtą bendrą Nemuno vagos ruožą nuo Gardino iki Smalininkų. Nemuno tyrinejjimo, reguliavimo ir valymo darbai buvo vykdomi 1803-1807, 1820-1825 bei 1874-1875 m. Nemuno žemupys su Klaipèdos uostu sujungtas 1863-1873 m. iškastu 24 km ilgio Karaliaus Vilhelmo kanalu, o upes vaga nuo Smalininkų iki Kuršių marių 1874-1892 m. sureguliuota būnomis. Nemuno 465 km 
ilgio ruožas - laivuojama upé, todèl joje būnų, žemsemių pagalba farvateryje buvo palaikomas $1,15-1,50 \mathrm{~m}$ vandens gylis. Labiausiai Nemuno vaga pakito vidurupyje tarp Prienų ir Kauno 1959 m., irengus 63,5 km² Kauno HE tvenkini, kurio vandenį naudoja ir Kruonio HAE.

Pagristai galima teigti, kad Nemunas buvo ir yra valstybinio masto vandens objektas. Nemuno verte ekonominiu, ūkiniu, estetiniu, moksliniu ir kitais požiūriais neįkainojama. Todèl apie šią upę iki šiol paskelbta dešimtys monografijų, straipsnių ir rašinių [6].

Mokslinių aprašymų apie Nemuno vagą, laivybos sąlygas, pakrantes ir gyvenvietes jose, su gyvais tyrinètojų ispūdžiais ir legendomis, galima rasti daugelyje darbų nuo XIX a. Tokio pobūdžio yra S. Moravskio kelionės $1858 \mathrm{~m}$. Nemunu nuo Merkinès iki Kauno aprašymas, minèta V. Sirokomlès knygutė (pakartotinai vertimas išleistas 1991 m.). 1888 m. Z. Glogeris aprašè Nemuno slènio geologiją, pakrančių įvairovę, statinius ir kt. nuo Gardino iki Kauno.

XIX a. pabaigoje ir XX a. pradžioje pasirodo darbų, kuriuose šalia aprašymų skelbiama inžinerinio-hidrologinio turinio žinių ir apibendrinimų. Iš tokių darbų paminètinas H. Kelerio 1899 m. paskelbtas darbas [6], kuriame aprašoma Nemuno, Priegliaus ir kitų upių baseinų fizinès geografinès sąlygos, upių tinklas, nuotèkis, vandens ūkis ir kt. Nemuno vagos savybès, upès vandeningumas, laivyba pateikiama V. Cholševnikovo darbe [7]. Konstatuotina, kad Nemunu jau nuo XX a. pradžios domètasi kaip hidroenergijos šaltiniu, pirmiausia Nemuno vidurupio didžiosiomis kilpomis. Čia pirmuosius tyrimus atliko ir siūlymus pateikẻ J. Merčingas [8], kurio idèją vèliau palaikè S. Kolupaila [9]. Galimybę elektrifikuoti Lietuvą Nemuno ir kitų upių hidroenergijos dèka pirmasis pagrindè ir siūlymus pateikè J. Smilgevičius [10]. Lietuvos inžinierių idèjos buvo realizuotos tik iš dalies - 1960 m. pastatyta Kauno HE ir kaip alternatyva Birštono HE - 1994 m. Kruonio HAE prie Kauno marių [11, 12]. Su Nemuno hidroenergijos panaudojimu buvo keliama idejja įruošti tarptautinį Nemuno-Dniepro vandens kelią [13]. Šiuo metu tvenkti Nemuną neleidžiama.

Apie Nemuno tyrimus plačiau galima sužinoti iš J. Macevičiaus straipsnio [14], M. Lasinsko sudarytos Lietuvos upių nuotèkio tyrimo darbų bibliografijos [6] ir jubiliejinio leidinio, skirto Lietuvos hidrometeorologijos istorijos apžvalgai [15], bei leidinio apie Lietuvos ir Kaliningrado srities hidrologinįi ištirtumą [16].

Kadangi mus labiau domina ne Lietuvos upių tyrimai bendrai, bet stacionarūs hidrometriniai tyrimai, kurie Nemune pradèti prieš 200 metų, todèl kiek plačiau panagrinèkime ši svarbų îvykị bei jo reikšmę praktikai ir mokslui.

\section{NEMUNO STACIONARŪS HIDROMETRINIAI TYRIMAI}

Siekiant plačiau panaudoti Nemuno gamtos išteklius, nuo $1803 \mathrm{~m}$. Rusija ir Prūsija ėmèsi tirti ir reguliuoti jo vagą. Buvo padaryta vagos nuotrauka nuo Gardino iki Smalininkų ir ịrengta 13 VMS. Šias stotis reikètų laikyti pirmosiomis, tačiau jų duomenų neišliko. Žymiai veliau (1876-1877 m.) Rusijos vandens kelių apygarda Nemune įsteige 15 VMS, iš kurių 8 - Lietuvoje, o Druskininkų ir Kauno VMS tebeveikia [16]. Tad pirmosiomis VMS laikytinos Nemuno žemupyje Prūsijos ịstaigų 1810-1812 m. j̧steigtas (pradèti stebèjimai) VMS. Tai nuo 18111001 Nemuno dešiniajame krante veikianti Smalininkų VMS ir nuo 18100822 Atmatoje veikianti Rusnès VMS. O Nemuno kairiajame krante Tilžès ir Sèlių (Kaliningrado srities teritorija) VMS buvo atitinkamai issteigtos 18110101 ir 18100726 [16]. Sèlių VMS laikytina pirmąja VMS Nemune, tačiau ji 1938 m. uždaryta. Šios keturios pirmosios VMS pagal nustatytą programą matavo ir matuoja upès vandens lygi, fiksuoja ledo reiškinius ir kitus hidrometeorologinius elementus, tačiau Nemuno nuotekis deltos pradžioje nustatomas pagal Smalininkų VMS duomenis (1 pav.). Smalininkų VMS, kurios 200 metų veiklos jubiliejų pažymėsime $2011 \mathrm{~m}$. spalio $1 \mathrm{~d}$., imponuoja hidrometrinių duomenų apimties unikalumu. Nors žinomas vokiečiu hidrologas H. Keleris yra pareiškęs, jog Tilžès VMS duomenys iki $1843 \mathrm{~m}$. yra patikimesni už Smalininkų VMS vandens lygių duomenis, S. Kolupaila, išstudijavęs abiejų stočių vandens lygius, padare išvadą, jog „Smalininkų medžiaga neblogesnè už Tilžès, o gal net geresnë“ [17]. Tai labai svarbi S. Kolupailos išvada, pagrindžianti išskirtinę Smalininkų VMS hidrometrinių duomenų reikšmę tarp kitų Nemuno žemupio stočių.

Hidrometrinių tyrimų pradžia Lietuvoje laikomi $1921 \mathrm{~m}$., kai Respublikos Vyriausybe išleido atitinkamą nutarimą, tačiau praktiškai jie prasidejjo 1923 m., S. Kolupailos pastangomis prie Plentų ir vandens kelių valdybos ịsteigus Hidrometrinę partiją, nuo 1930 m. pavadintą Hidrometriniu biuru. Jos tikslai gana platūs: bendri Lietuvos vandens tyrimai, vandens matavimo stočių steigimas, upių vandens debitų tyrimas, suinteresuotų organizacijų aprūpinimas hidrometrine medžiaga ir kt. Turimomis žiniomis [15], Lietuvoje $1923 \mathrm{~m}$. veike 34, 1935 m. - 92, o iš viso iki 1944 m. - 158 VMS. Leidinyje [1] Lietuvos upių nuotèkio charakteristikos apskaičiuotos pagal 160 VMS duomenis. Tai rodo, kad Lietuva hidrologiškai pakankamai ištirta. Šiuo metu hidrometeorologinę šalies būseną stebi ir tiria Lietuvos hidrometeorologijos tarnyba prie Aplinkos ministerijos, o upių nuotèki - šios tarnybos Hidrologijos skyrius. Skyriaus žinioje $2008 \mathrm{~m}$. buvo 68 vandens matavimo stotys prie Lietuvos upių ( 9 iš jų prie Nemuno) ir 7 prie ežerų ir Kauno HE tvenkinio [18].

Pirmieji Nemuno stacionarūs hidrometriniai tyrimai buvo pradèti jo žemupyje. Ta Nemuno dalis buvo Prūsijos žinioje. S. Kolupaila, dirbęs Lietuvos hidrometrinio biuro vedèju, Smalininkų VMS 1811-1929 m. hidrometrinius rankraštinius duomenis gavo iš Klaipèdos uosto ir Prūsų hidrologinio instituto (Berlyne), kruopščiai juos išnagrinejjo ir 1930 m. paskelbè Hidrometrinio metraščio II tome [17]. Šiame, be galo svarbiame, leidinyje autorius pateikia nuo matavimų pradžios VMS ịrengimo ir rekonstrukcijos aplinkybes, kasdienius vandens lygius, ju grafikus, atžymas apie ledo reiškinius per 1811-1930 m. bei Nemune 1875-1930 m. 


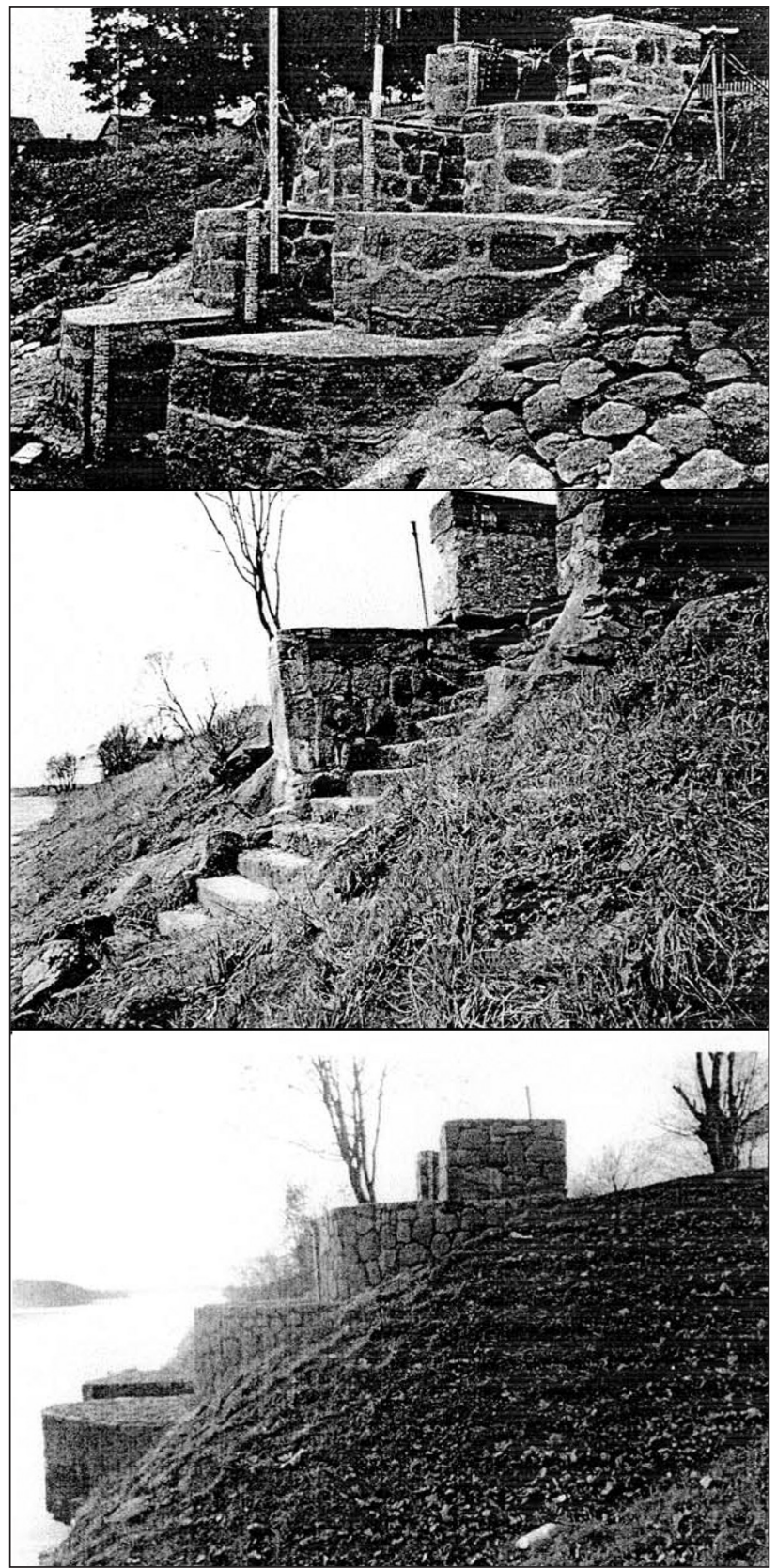

1 pav. Smalininkų vandens matavimo stotis 1928 m., apgriauta po 1979 m. pavasario potvynio ir restauruota $2004 \mathrm{~m}$.

atliktus vandens debitų matavimus, pagal juos sudarytą Smalininkų VMS debito kreivę ir pagal ją apskaičiuotus 10 metų (1920-1929) kasdienius upès vandens debitus. Šis darbas sulaukè pasaulio, ypač Baltijos regiono hidrologų dėmesio. Tačiau tęsdamas Nemuno tyrinèjimą S. Kolupaila pasauliui pateikè antrą hidrologinę staigmeną - unikalius, 121 metų (1812-1932) nuotèkio duomenis [19]. Kas per žmogus buvo Steponas Kolupaila (2 pav.) ir ką jis davé Lietuvai - įvertinta $[6,15,20,21$ ir kt.] darbuose.

S. Kolupailos dèmesys Nemunui tęsèsi visą jo gyvenimą (1892-1964). Pažintinę vertę turi taip pat S. Kolupailos $1940 \mathrm{~m}$. paskelbta populiari mokslinè monografija apie Nemuną [22]. Tarpukariu (1920-1940) jis vadovavo tyri-

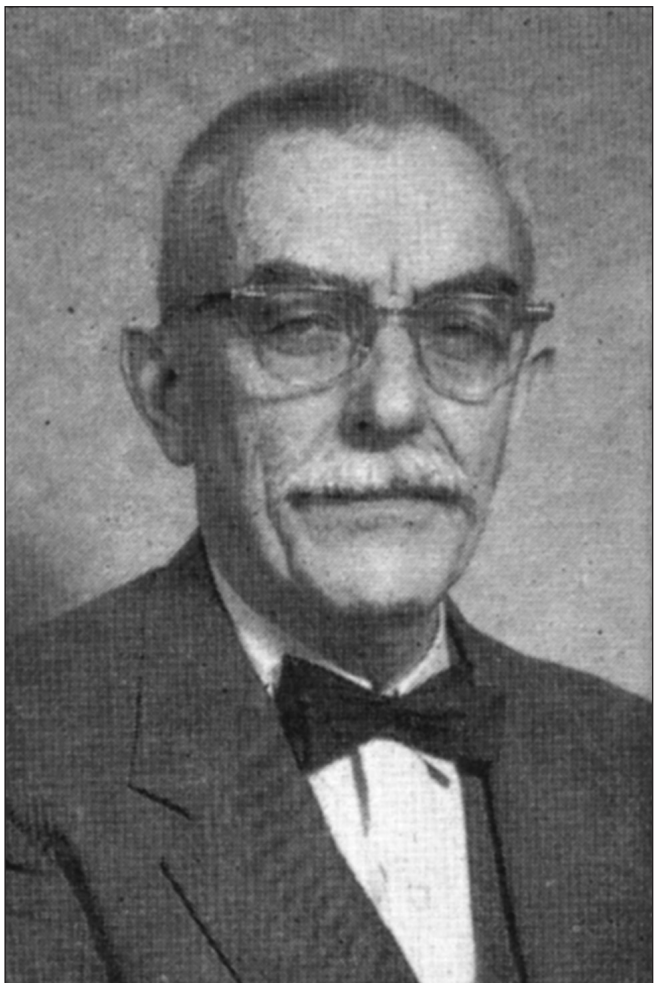

2 pav. Profesorius Steponas Kolupaila (1892 09 14-1964 04 09)

mams ir kaupe duomenis apie Lietuvos upes. Gyvendamas užsienyje $1961 \mathrm{~m}$. išleido kapitalinį veikalą "Bibliography of Hydrometry" su 6080 literatūros šaltinių [23]. S. Kolupaila perprato hidrometrijos mokslinę ir praktinę vertę, parašè ir paskelbè unikalią 2 tomų „Hidrometriją“ [24], irengè pirmąją Pabaltijyje vandens malūnèlių taravimo laboratoriją, pasiūlè originalią metodiką upių nuotèkiui po ledu skaičiuoti. Ne viename savo darbe jis pabrèžia, kad „svarbiausias hidrologinis elementas - upių vandens debitas, pagal kuri skaičiuojamas upės baseino nuotakis“. Vandens horizontu ir debitu svyravimuose jis ižvelge klimato kaitos išraišką. Tikslinga pacituoti jo mintį, išreikštą [17] darbe: „Vandens horizonto svyravimai charakterizuoja nuotakị nuo viso upès baseino. Upé, kaip klimato funkcija, integruoja ịvairius oro klimato elementus. Jos debituose, o kartu horizontuose, atsispindi tiek oro svyravimai metu remuose, tiek nepastovaus klimato ilgametes bangos arba šuoliai. Upių užšalimo bei paleidimo datos laikomos raiškiausiomis žiemos ribomis; ilgos jų eilès nepaprastai brangios klimatologijai“. S. Kolupaila labai vaizdžiai parodo būtinumą turèti tokią ilgalaikę duomenų eilę. Jis sako, kad ,jei nuotakis rodo tendenciją vis eiti mažyn, daroma išvada, kad kraštas džiūsta, primetama kaltė miškų naikinimui, balų sausinimui, upių reguliavimui... Atvirkščiai, jei nuotakis eina didyn, ieškoma kitų priežasčių; jų neradus Žemèje, įtariamos Saulès dèmès ir Mènulio paslaptinga įtaka" [19]. Tačiau apie klimato kaitos ir nuotèkio santykị kalba tik užuomina, kad „kraštas džiūsta“, tačiau džiūsta neaišku kodèl - ar dèl aukštesnès oro temperatūros, ar mažesnių kritulių? 
Taigi Nemuno 200 metų hidrometriniai duomenys vertingi ne tik praktiniu, bet ir moksliniu bei diskusinio pobūdžio klimato kitimo išryškinimo požiūriu. Ryšium su tuo, labai svarbu ịvertinti išmatuotų ir apskaičiuotų hidrometeorologinių duomenų patikimumą.

\section{NEMUNO TIES SMALININKAIS DUOMENŲ PATIKIMUMAS}

Tai svarbus klausimas tiek vandens telkinių hidrologiniuose tyrimuose, tiek atliekant bet kuriuos hidrometeorologinius skaičiavimus. Žinoma, upių vandens matavimai ir skaičiavimai atliekami prisilaikant normatyvų ir instrukcijų. Tačiau ilgas eiles turinčių duomenų vienareikšmiškumas gali pakisti dèl daugelio priežasčių: matuoklès „0“ pakitimo ją atstatant po pažeidimų potvynio metu; upès vagos formos ir dugno pakitimo; grunto išplovimo ar sąnašų klostymosi; matavimų sutrikimo ir atstatytų duomenų; priežiūros bei matavimo taisyklių nesilaikymo ir daugelio kitų priežasčių.

Problemų nustatant vandens lygius bei apskaičiuojant upès nuotèkị būta ir Smalininkų VMS. Pirmosios matuoklès buvo netobulos, dažnai sulaužomos ledų ir vèliau atstatomos pagal išlikusias apatines dalis, todèl susidarydavo neišmatuotų vandens lygių spragos. Stotis nukentëjo nuo $1827 \mathrm{~m}$. Nemuno potvynio. $1842 \mathrm{~m}$. pertvarkytos matuoklès, tačiau ir po to nuo ledų ir bangavimo kasmet nukentėdavo jų apatinės dalys. 1888 m., pastačius Smalininkų uostą, stotis rekonstruota, pastatyti kapitaliniai mūriniai laiptai, tačiau jų viršutinè dalis su įrengtu reperiu ir matuokle per $1928 \mathrm{~m}$. pavasario potvyni buvo apgriauti, bet atstatyti, tačiau po 1979 metų audringo pavasario potvynio unikalus statinys tapo avarinès būklès ir dèl lèšų stokos kurị laiką nebuvo atstatytas (1 pav.). Matavimai buvo atliekami ant šalia statinio ịkaltų metalinių polių su matuoklèmis. Stotyje $1961 \mathrm{~m}$. pastatyta būdelè ir įrengtas savirašis (limnigrafas). Smalininkų VMS yra Lietuvos kultūros paminklų sąraše, todèl $2004 \mathrm{~m}$. ji restauruota [25].

Nuo 1845 m. stotis inspektuojama vieną kartą per metus, protokole nurodant rastus trūkumus, todèl stotis, anot S. Kolupailos, buvo gerai prižiūrima [17]. Per sunkmečius, dažniausiai karus, stebejjimai nebuvo atliekami. 1812 m. pradžios, 1817, 1914 ir 1915 m. kelių mėnesių duomenys buvo redukuoti iš Tilžès VMS. Nuo 1811 iki $1925 \mathrm{~m}$. vandens lygis buvo matuojamas 12 valandą, nuo 1925 m. - 7, 13 ir 19 valandomis. Laikantis naujos (1871 m.) instrukcijos stotyje nuo 1872 m. ịvesti metriniai matai kartu su prūsiškais, pakeistos matuoklès, reperis ir kt.

Nuo 1901 m. Smalininkų VMS vandens lygio duomenys buvo skelbiami Prūsų hidrologinio instituto metraščiuose. S. Kolupaila, palyginęs savo duomenis su vokiečių duomenimis, rado nežymių skirtumų [17]. Todèl jis buvo ịsitikinęs, kad dèl 1830-1929 m. duomenų tikrumo abejonių nekyla, ypatingų netikslumų nematė ir ankstesniuose duomenyse. Taigi S. Kolupaila kvalifikuotai įvertino gautą archyvinę Smalininkų VMS vandens lygių medžiagą ir ją paskelbè. Anot S. Kolupailos [19], „mums pavyko surinkti, patikrin- ti pagal originalus, sutvarkyti ir išleisti visas observacijas, kurių vertė yra neįkainojama [...]. Gražiai išspausdinta brangių observacijų medžiaga sudare ispūdžio ir užsienio hidrologams“. Tačiau sulaukė ir „naudingos“ kritikos. Susidaro įspūdis, kad S. Kolupaila manè, jog ịvertinęs vandens lygių duomenis su tam tikromis prielaidomis, nesunkiai išsprendè ir nuotėkio klausimą. Iš 96 netoli Smalininkų VMS išmatuotų Nemuno vandens debitų (tarp Dubysos ir Šešupès žiočių) juos redukavus ị Smalininkus, buvo sudarytos debito kreivès, lygtys žemiems $(h \leq 3,0 \mathrm{~m})$ ir aukštiems $(h>3,0 \mathrm{~m})$ vandens lygiams bei skaičiavimų lentelè. Matyti, jog autoriui labai rūpejo sužinoti, kiek Nemunu teka vandens, todèl buvo „padarytas bandymas skaičiuoti metinị nuotakị". Tam bandymui buvo pasirinktas 1920-1929 m. dešimtmetis, kurio apskaičiuotas kiekvienos dienos nuotèkis. To dešimtmečio Nemuno ties Smalininkais vidutinis metinis nuotèkis gautas $554 \mathrm{~m}^{3} / \mathrm{s}$, arba $17,5 \mathrm{~km}^{3}$ per metus. Tačiau, susidomèjęs Nemuno ties Smalininkais vandens lygių duomenimis ir sudarytomis debito kreivėmis bei lygtimis, H. Renkvistas (Suomija) pratęsè „,bandymą“ dešimtmečiais ir pastebejo, kad Nemuno nuotekis eina vis didyn, per šimtmetị išaugo nuo 12,5 iki 17,5 km³ per metus. Ši žinia, paskelbta $1931 \mathrm{~m}$. Suomijos geografų žurnale, paragino S. Kolupailą tiksliau apskaičiuoti Nemuno nuotèki. Jis pastebėjo ir prièjo išvadą, kad vidutiniai metiniai vandens lygiai pakilo $0,5-0,6 \mathrm{~m}$ per 100 metų dèl iš aukščiau atnešamo smèlio $[19,22]$. Ivedęs pataisą i vandens lygius dèl upès dugno kilimo S. Kolupaila apskaičiavo ir 1933 m. IV Pabaltijo hidrologų konferencijoje paskelbė Nemuno ties Smalininkais 1812-1932 m. nuotèkio duomenis [26], kur sulaukè žymių hidrologų pritarimo bei švelnios kritikos.

M. Lasinskas, rašęs daktaro disertaciją apie Nemuno nuotėkio režimo dėsningumus, Smalininkų ilgalaikius duomenis vertina palankiai $[27,28]$, tačiau pažymi, kad nors S. Kolupailos hipotezė apie upès slènio ir dugno kilimą iš principo yra teisinga, bet kilimas yra padidintas dèl neįvertinto upès vandeningumo kitimo. Konkrečiai nurodo, kad 1812-1827 m. nuotèkio duomenis reikètų laikyti apytikriais; vidutinis metinis nuotekis ir maksimalūs debitai nuo 1828 m. visiškai patikimi ir tapatūs; minimalūs debitai patikimi nuo $1890 \mathrm{~m}$.

S. Kolupaila, sudarydamas metodiką Nemuno nuotèkiui ties Smalininkais apskaičiuoti, prièmè dvi prielaidas: upès dugno kilimą dẻl atnešamo smèlio ir debito kreivių tinkamumą laikotarpiui kol dar nebuvo toje vietoje matuojami vandens debitai. Jis buvo įsitikinęs, kad dugno kilimą eliminavo i vandens lygio duomenis ịvedęs pataisas, nustatytas pagal 1812-1869 ir 1870-1929 laikotarpių vidutinių vandens lygių skirtumą: $\Delta h=247-215=32 \mathrm{~cm}$, nors kartu išreiškè nuomonę, kad būtu gerai surinkti kritulius Nemuno baseine ir ìvertinti klimato veiksnių įtaką upès vandens lygiui [26]. Šią aplinkybę ištyrème nagrinėdami Pabaltijo hidrometeorologinių elementų šimtmetinį cikliškumą ir tų laikotarpių klimato skirtumus, galëjusius turèti ịtakos Nemuno vandens lygiui. Iš tikrųjų tirtų klimato elementų (oro temperatūrų, kritulių, 
ledo reiškinių ir kt.) tais laikotarpiais skirtumai siekè 6-13 \% normų. Todèl manome, kad iš viso $32 \mathrm{~cm}$ vandens lygio skirtumo $21 \mathrm{~cm}$ yra sąlygojamas klimato cikliškos kaitos ir $11 \mathrm{~cm}$ - upés dugno kilimo [29]. Nepaisant to, Nemuno ties Smalininkais beveik 200 metų nuotèkio šimtmetinëje kaitoje, kaip ir daugelio klimato elementų kaitoje, išliko cikliškas pobūdis. Nemuno ties Smalininkais hidrometriniai duomenys unikalūs apimtimi ir beveik idealūs tikslumu, svariai praverčia bei pravers praktikai ir mokslui.

\section{NEMUNO NUOTĖKIS IR JO KAITA}

Pirmieji Nemuno ties Smalininkais kiekvienos dienos debitai (bandomieji) per 1920-1929 m. paskelbti $1930 \mathrm{~m}$. [17]. Vèliau, 1932 ir 1933 m., buvo paskelbti 1812-1932 m. vidutiniai hidrologinių metų ir būdingi vandens debitai $[19,26]$. Reguliariai Nemuno ir kitų upių kiekvienos dienos vandens lygis ir nuotekis buvo skelbiami pokariniuose ir laisvos Lietuvos hidrologijos metraščiuose iki šiol. $1950 \mathrm{~m}$. metraštyje [30] skelbiami naujai apskaičiuoti 1932-1943 m. ir perspausdinami [17] darbe pateikti 1811-1932 m. vidutiniai mènesiniai, metiniai bei didžiausi ir mažiausi debitai, kai kurie iš jų pataisyti. Visi turimi Nemuno ir kitų upių nuotèkio duomenys iki $1962 \mathrm{~m}$. paskelbti tęstiniame leidinyje [31]. Nemuno ties Smalininkais, Lampedžiais, Birštonu, Gardinu ir Stolbcais nuotèkis ir jo charakteristikos, nuo matavimų pradžios iki 1955 m. imtinai, su komentarais paskelbti monografijoje [32]. Tenka apgailestauti, jog iki šiol dar nepaskelbti kiekvienos dienos nuotékio archyviniai duomenys.

Nemuno ties Smalininkais nuotekio bei jo režimo ilgalaikiai duomenys labai vertingi moksliniu požiūriu, nes iggalina lyginti upių nuotekị ir klimato veiksnius, pagrịstai spręsti apie upių nuotèkio kilmę, nuotèkio skirtumus tarp upių, pagristi ir tikslinti nuotèkio statistinius parametrus, nuotekkio kaitos pobūdị ir jos priežastis bei daugelị kitų klimato ir hidrologijos klausimų.

Galima išvardyti daugelį mokslininkų, kurie savo atliktuose tyrimuose panaudojo Nemuno ties Smalininkais hidrometrinius duomenis. Pirmasis 1934 m. Nemuno ties Smalininkais vandens horizontų kaitą bei upès užšalimo ir nuledejjimo datas tyrẻ V. Šostakovičius. Tyrimo rezultatai paskelbti lietuviškoje spaudoje [33] su gana optimistiškomis išvadomis. Autorius nustatė, kad tirtų elementų svyravimų periodai artimi 3, 6, 11 ir 30 metų. Jis teigia, kad upių režimo periodiški svyravimai, tarp kitų ir Nemuno, neabejotinai susiję su analogiškais klimato elementų periodiškais svyravimais ir mano, kad tai „Saulés veikimo periodiškų kitimu rezultatas". Iš tikrųju, isitikinome, kad Nemuno nuotékis per 180 metų kito skirtingo vandeningumo laikotarpiais - serijomis, kurios truko ilgiau nei atsitiktinių dydžių serijos; apčiuoptas metinio nuotèkio daugiametès kaitos reguliarumas. Tikètiniausi yra 5-6, 15, 25-28 ir apie 90 metų kaitos periodai. Nemuno metinio nuotèkio kaitai būdingas cikliškumas ir paprastos Markovo grandinès procesas [34].
J. Macevičius Nemuno ir kitų upių nuotėkio svyravimus lygino su oro temperatūros bei kritulių svyravimais ir patvirtino išvadą, kad tarp nuotèkio ir temperatūros didžiuosiuose cikluose yra aiškiai išreikšta atvirkštinè priklausomybė [35]. Monografijoje [36] M. Lasinskas ir J. Burneikis nurodo pakankamai glaudų Nemuno ties Smalininkais nuotèkio ir Vilniaus MS kritulių ryšį. Išnagrinèję upių nuotekio daugiametės kaitos pobūdị nustateme, kad tai klimato fluktuacijų ir sąveikos su teritorijos landšaftu išdava; hidrologinių procesų gamtinę daugiametę ciklinę kaitą sąlygoja drègmès ir šilumos tarpusavio santykis [37].

Pastaruoju metu, kaip manoma, vykstant klimato atšilimo procesams, galimi upių nuotékio bei vandens išteklių pokyčiai lydimi antropogeninès veiklos. J. Kriaučiūnienė [38] ir D. Meilutytė-Barauskienè [39] apibendrino Lietuvos energetikos instituto Hidrologijos laboratorijoje, bendradarbiaujant su Šiaurès šalių hidrologais, atliktus tyrimus ir nustaté, kad ryšium su klimato atšilimu Lietuvos upių nuotekis dideja žiemos sezonu, pavasario potvynis mažèja ir prasideda anksčiau, mažiausiai pakinta vasaros ir rudens upių nuotèkis. Tai aiškinama tuo, kad pakilus oro temperatūrai sniego danga tirpsta anksčiau ir padidejja žiemos sezono nuotèkis pavasario nuotèkio sąskaita. Pritaikę naujausius globalinès oro cirkuliacijos modelius įvairiems dujų emisijos srautams, $[38,39]$ darbų autoriai atliko oro temperatūros, kritulių ir upių nuotèkio XXI amžiui būsenos prognozę. Išvados šios: visų metų sezonų vidutinè oro temperatūra per 100 metų (2001-2100) padidès iki $4,6^{\circ} \mathrm{C}$, labiausiai oras atšils žiemą, kritulių ryškaus pokyčio neprognozuojama, jų kiek padaugès žiemą, mažiau - pavasarị. Ryšium su tuo prognozuojama, kad Nemuno vidutinis metinis nuotèkis per šimtmetị sumažès 13,6 \%, palyginti su 1975-1984 m. nuotèkiu.

Iki šiol neaišku, ar šylant klimatui išliks klimato elementụ ir upių nuotekio ciklinè kaita ir kaip ji bus transformuota? Tai i̇domu praktiniu ir moksliniu požiūriais.

Reikia atkreipti dèmesị $\mathfrak{i}$ tai, jog Nemuno ties Smalininkais nuotekis iš dalies apibūdina kitu šalies upių, kurių dauguma yra Nemuno intakai (pabaseiniai), nuotèki, ypač Pietryčių upes ir Nerí, kiek mažiau Vidurio ir Vakarų Lietuvos upes. Nemunas savitą nuotèkio režimą igauna nuo aukštupio ir Neries.

Išsiaiškinus Nemuno atliekamų hidrometrinių tyrimų ir sukauptų 200 metų hidrologinių duomenų svarbą, pravartu juos glaustai pateikti. 3 pav. pamečiui nuo 1812 iki $2010 \mathrm{~m}$. pavaizduoti kiekvienų metų vidutiniai, didžiausi ir mažiausi vandens debitai. 1943-1946 m. duomenys, kai Smalininkų VMS dèl karinių sutrikimų neveike, atstatyti pagal Lampèdžių VMS.

Išsami Nemuno nuotèkio analizė atlikta anksčiau cituotuose darbuose, tačiau 3 pav. grafiškai pavaizduoti pagrindinių nuotèkio charakteristikų ištisiniai duomenys igalina atsekti upès nuotèkio kaitos mastą ir jo kitimo laike tendenciją (trendą), laikant, kad 198 metų trukmès ištisiniai duomenys yra pakankamai tikslūs, tad ir lygiareikšmiai. 


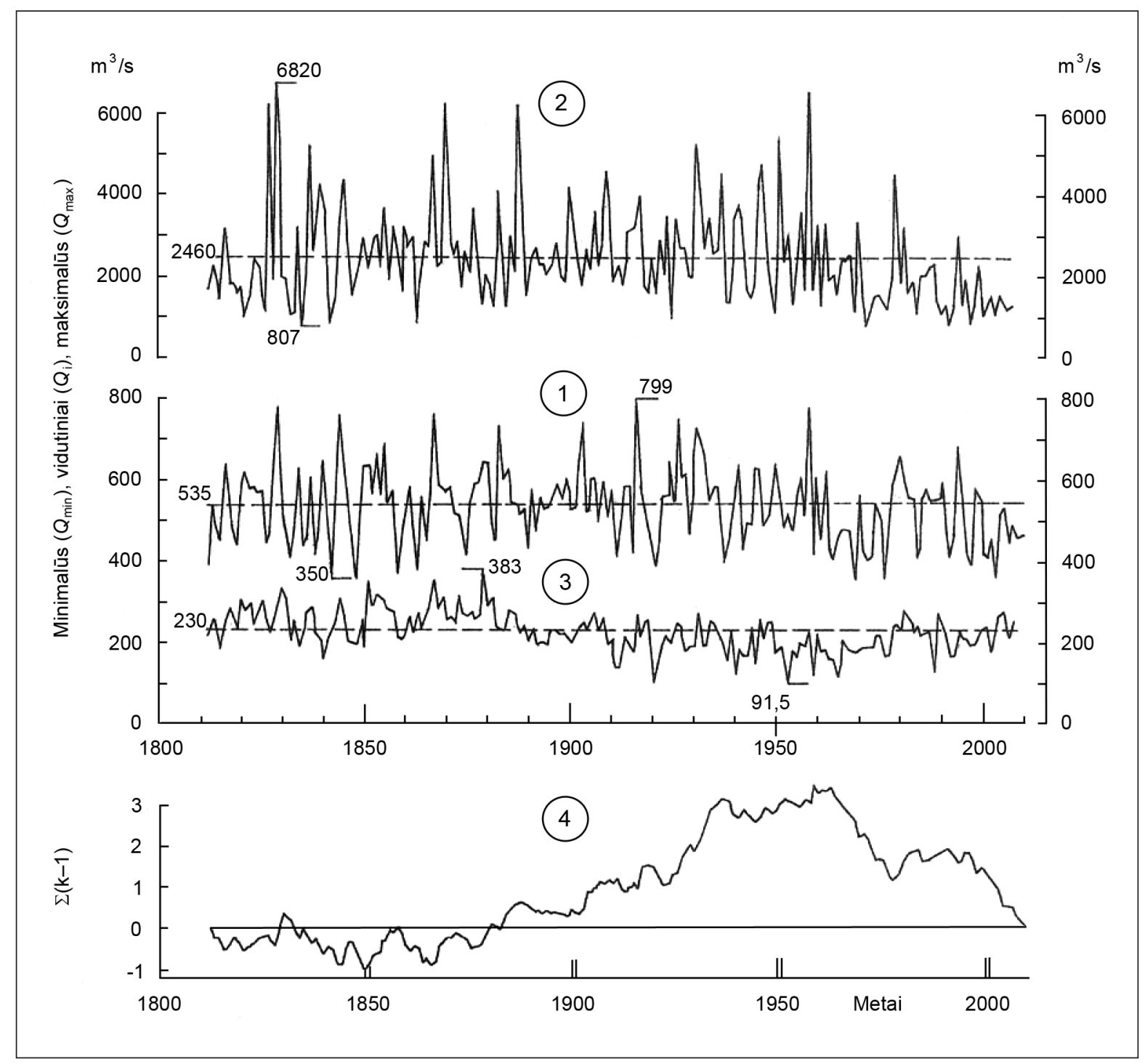

3 pav. Nemuno ties Smalininkais vidutiniai metiniai (1), kiekvienų metų maksimalūs (2), minimalūs (3) vandens debitai ir vidutinių metinių debitų integralinè kreivè (4)

3 pav. matyti, kad Nemuno ties Smalininkais vandens debitai per 198 metus (1812-2009) kito nuo didžiausio $6820 \mathrm{~m}^{3} / \mathrm{s}$, išmatuoto $1829 \mathrm{~m}$. balandžio $12 \mathrm{~d}$., iki mažiausio $91,5 \mathrm{~m}^{3} / \mathrm{s}$, išmatuoto $1953 \mathrm{~m}$. gruodžio $23 \mathrm{~d}$., t. y. didžiausias mažiausią vandens debitą viršijo 75 kartus. Pasekime, kaip kito kai kurios nuotekio charakteristikos. Jų didžiausios ir mažiausios reikšmių skirtumas arba variacinis plotis $A$ šitoks: vidutiniai metiniai debitai $A_{1}=799-350=449 \mathrm{~m}^{3} / \mathrm{s}$, maksimalūs debitai $A_{2}=6820-807=6013 \mathrm{~m}^{3} / \mathrm{s}$, minimalūs debitai $A_{3}=383-91,5=291,5 \mathrm{~m}^{3} / \mathrm{s}$. Šių nuotèkio charakteristikų didžiausio ir mažiausio debitų santykis yra atitinkamai 2,3, 8,5 ir 4,2. Atsižvelgus ị tai, kad pagrindinis kaitos matas vidutinis kvadratinis nukrypimas arba standartas $S$, kai duomenų $n>50$, sudaro $S \approx 0,2 A$, matyti, kad mažiausiai kaitūs yra vidutiniai metiniai vandens debitai, labiausiai - maksimalūs ir mažiau - minimalūs.

Nemuno nuotèkis, taikant matematinès statistikos ir tikimybių teorijos metodus, gana detaliai išnagrinètas $[1,24$,
28, 32, 34 ir kt.] darbuose. Juose pateikta daug originaliu ir vertingu išvadụ bei siūlymu apie Nemuno upès vandens daugiametį režimą ir vandens išsteklių praktinị panaudojimą. Pabrèžtina, kad Nemunas yra ne tik viena didžiausių Baltijos regiono upių, bet ir sukaupti dviejų šimtmečiu nuotèkio duomenys leidžia spręsti apie ilgo laikotarpio šio regiono upių nuotèkio režimą. Nemuno nuotèkio ilgalaikiai duomenys igalina ne tik pagrịsti ar patikrinti žinomų statistikos rodikliu santykius, bet ir išryškinti nuotèkio kaitos šimtmetines tendencijas. Pikų ir slènių išsidèstymas 3 pav. chronologiniuose grafikuose rodo nuotèkio pametinio kitimo suintensyvejjimą arba jo ramesnę eigą. XIX a. 3-4 ir 7-8 dešimtmečiais buvo permainingas Nemuno nuotèkio režimas, po to aukšti buvo 1947, 1951, ypač 1958 m. pavasario potvyniai. Tuo tarpu nuo 1980 iki 2009 m. potvynių nejautėme. Nemuno minimalūs debitai nuo nagrinėjamo laikotarpio pradžios maždaug iki $1880 \mathrm{~m}$. buvo kiek didesni nei vèlesnio laikotarpio, todèl minimalaus nuotèkio duomenys iki $1890 \mathrm{~m}$. ir vélesnio periodo 
laikomi nevienalyčiais [27]. Tačiau nuo $1980 \mathrm{~m}$. minimalūs debitai ima didèti, o maksimalūs debitai - mažèti. Kodèl taip vyksta - nagrinètinas klausimas.

Atsižvelgiant $\mathfrak{i}$ vandens išteklius labai svarbūs yra upių vidutiniai metiniai vandens debitai. 3 pav. vidutinių metinių debitų chronologinis grafikas nerodo ryškių pametinių kaitos tendencijų. Tačiau jos ryškejja, kai duomenys pavaizduojami vadinamuoju nukrypimų nuo daugiamečio vidurkio pametinėmis sumomis arba vadinamuoju integralinès kreivès grafiku, tiksliau - laužtinių atkarpų grafiku, kuriame kiekvienos atkarpèlès pasvirimas rodo nuotèkio dydį. Kylanti 1 metų atkarpèlè ar kelerių metų atkarpa, jų polinkis (statumas) rodo atitinkamai didesnį už daugiametị vidurkị dydị, žemèjanti kreivès dalis - dydị, mažesnį už vidurkị. Iš tikrųjų 3 pav. 1 ir 4 kreives yra identiškos. Tokios kreivès dažnai naudojamos hidrologiniuose tyrimuose, nes pagal jas lengva nustatyti duomenų pametinị kaitos pobūdị. Šiuo būdu panagrinèkime Nemuno ties Smalininkais vidutinị metinị nuotèkị, išreikštą vandens debitais.

Nemuno ties Smalininkais debito, tirto 1812-2009 m. (198 metai), vidurkis $\bar{Q}=535 \mathrm{~m}^{3} / \mathrm{s}$. Sudetti paeiliui kiekvienų metų modulinių koeficientų $k_{i}=Q_{i} / \bar{Q}$ nukrypimai nuo vidurkio $\Sigma\left(k_{i}-1\right)$ pavaizduoti 3 pav. 4 kreiveje. Ji rodo ir vienų, ir iš eilès einančių kelerių metų bei ilgesnio laikotarpio nukrypimų nuo vidurkio dydį. Pirmiausia šioje kreivẻje išryškèja du būdingi lūžio taškai. Pirmas ties $1850 \mathrm{~m}$., antras - ties $1963 \mathrm{~m}$. Aiškiai išsiskiria trys laikotarpiai: neryškus nuotèkio sumažèjimas 1812-1849 m., padidejjusio nuotèkio 1850-1962 m. laikotarpis ir vèl sumažèjusio nuotékio 1963-2009 m. laikotarpis. Pirmu, 38 metų trukmés, laikotarpiu Nemune ties Smalininkais tekèjo vidutiniškai $521 \mathrm{~m}^{3} / \mathrm{s}$ vandens. Tai $14 \mathrm{~m}^{3} / \mathrm{s}$ vandens $(2,6 \%)$ mažiau nei daugiametis vidurkis. Antru, 113 metų, laikotarpiu tekèjo vidutiniškai $556 \mathrm{~m}^{3} / \mathrm{s}$ vandens. Tai $21 \mathrm{~m}^{3} / \mathrm{s}$ vandens $(3,9 \%)$ daugiau nei daugiametis vidurkis. Trečias, mūsų gyvenimą labiausiai palietęs 47 metų, laikotarpis buvo mažiausiai vandeningas. Nemunu tekejjo tik $495 \mathrm{~m}^{3} / \mathrm{s}$ vandens, arba $40 \mathrm{~m}^{3} / \mathrm{s}(7,5 \%)$ mažiau nei vidutiniškai per visą tiriamą laikotarpị. Šitiek vandens ị Nemuną plukdo jo intakai Jūra arba Minija. Labai svarbu išsiaiškinti, ar tai ryškūs nukrypimai nuo daugiamečio vidurkio. Stjudento $t$ kriterijumi buvo tikrintos nulinès hipotezės $H_{0}: \bar{Q}_{k}=\bar{Q}_{n}$. Esant patikimumo lygmeniui $\alpha=0,05, H_{0}$ hipotezè priimtina tik pagal pirmojo laikotarpio $k=38$ metų duomenis, antro $(k=113)$ ir trečio $(k=47)$ laikotarpių vidurkiai alternatyviai laikomi esminiai nutolę nuo daugiamečio vidurkio.

Iš integralinès kreivès matyti, kad nuotèkio kaitoje išsiskiria ịvairios trukmès laikotarpiai, vadinami ciklinio svyravimo fazėmis, kurių reikšmès esminiai nutolusios nuo daugiamečio vidurkio. Nustatyta, kad Nemuno ties Smalininkais 12 vienerių metų, 16 ịvairaus ilgio (nuo 2 iki $61 \mathrm{~m}$.) nuotèkio vidurkiai yra reikšmingai nutolę nuo daugiamečio vidurkio [34].

Nemuno ilgalaikiai duomenys ir jų analizès rezultatai rodo, kad egzistuoja hidrologinė nuotèkio skaičiavimo problema, susijusi su nuotèkio šimtmetiniu svyravimu. Šis klausimas iš dalies sprendžiamas, kai ịvertinant hidrometeorologinę charakteristiką priimamas standartinis 30-ties iš eilès einančių metų laikotarpis. Pasaulinè meteorologijos organizacija, tirianti globalinius klimato pokyčius, pasirinko 30 metų (1961-1990) standartinį laikotarpị. Hidrologai, skaičiuodami upés nuotèkio pokyčius, taip pat laikosi šios nuostatos. Mat laikotarpis pakankamai ilgas, nes jame telpa maždaug tokios trukmès stebimas nuotèkio kaitos ciklas. Pažiūrèkime, kaip jis atsispindi Nemuno ties Smalininkais duomenyse. $1961-1990 \mathrm{~m}$. standartiné norma $\bar{Q}_{30}=507 \mathrm{~m} / \mathrm{s}$. Tai $28 \mathrm{~m}^{3} / \mathrm{s}$, arba 5,2 \% mažesnè už daugiametį vidurkị. Nors pagal Stjudento $t$ kriterijų, kai $\alpha=0,05, H_{0}$ priimama, tačiau yra arti atmetimo ribos $\left(t_{30}<t_{196 ; 0,05}=1,84<1,96\right)$.

Kokia bus Nemuno nuotèkio kaita ir jos kitimas dèl klimato atšilimo, sunku spręsti, tačiau ši, jau nuo 1995 m. trunkantị, sumažèjusio vandeningumo laikotarpi turi pakeisti vandeningesnis laikotarpis, o $2010 \mathrm{~m}$. patvinusios upès galbūt yra tokio laikotarpio pradžia. Tačiau anksčiau minètos sumodeliuotos prognozès rodo, kad Nemuno nuotèkis dèl klimato atšilimo XXI a. sumažès vidutiniškai $14 \%$. Tad trečiasis palyginti mažo nuotekio laikotarpis nuo $1963 \mathrm{~m}$. bus labai ilgas, tačiau manome, kad ir dèl klimato atšilimo upių nuotèkis kis cikliškai. Tiriant toliau pravartu išsiaiškinti, kokios priežastys tirtu laikotarpiu nulèmè Nemuno nuotèkio kaitą. Jos iš dalies aiškios. Tai cikliškai kintančios klimato sąlygos ir konkreti antropogeniné veikla upés baseine. Pastarosios sukeltas poveikis ịsipina ị nuotèkio ciklišką kaitą, ją padidindamas ar sumažindamas, tačiau antropogenini poveikị nuotekkio kaitai išskirti sunku. Nustatyta $[1,38]$, kad Nemuno nuotèkį paveikẻ 1959 m. ịrengtas Kauno HE tvenkinys, turintis nežymų sezoninị ir paros nuotèkio reguliavimą, todèl iki $9 \%$ sumažejo Smalininkų VMS pavasario potvynių nuotèkis, šiek tiek padidèjo minimalūs paros debitai. Nuo $1976 \mathrm{~m}$. nuotèkis Nemune ties Smalininkais sumažějo $12 \mathrm{~m}^{3} / \mathrm{s}$, nes šis vandens kiekis iš Neries aukštupio permetamas ị Dniepro baseiną (VileikosMinsko vandens sistema). Nuo 1933 m. Nemunas per Nevěži gauna apie 3,6 m³ $/ \mathrm{s}$ vandens iš Mūšos baseino. Nedidelis kiekis nuotèkio iš Dubysos aukštupio per Kulpę patenka į Mūšą. Nesutariama, kiek paveikè Nemuno nuotèkị atliktas žemių sausinimas ir įrengti tvenkiniai. Manome, kad dèl išvardytų priežasčių Nemunas ties Smalininkais netenka apie 2-3 \% metinio nuotékio.

Pažymint Nemuno 200 metų stacionarius hidrometrinius tyrimus, būtina pabrežti jų svarbą šalies ūkiui ir mokslui ir su padèka prisiminti žmones, įnešusius svarų indèlį tiriant upes ir apskritai gamtą. Galime didžiuotis turèdami vieną ilgiausiai stebimų upių Europoje - Nemuną.

\section{IŠVADOS}

1. Smalininkų VMS, kurios 200 metų nepertraukiamos veiklos jubiliejų pažymèsime $2011 \mathrm{~m}$. spalio $1 \mathrm{~d}$., turi vieną ilgiausių nuotekio duomenų eilių pasaulyje, hidrologus imponuoja hidrometrinių duomenų apimties unikalumu. 
2. Kaupiant ir tvarkant Smalininkų VMS hidrometrinę medžiagą daug pasidarbavo žymus Lietuvos hidrologas Steponas Kolupaila, 1933 m. paskelbęs 1812-1932 m. Nemuno ties Smalininkais nuotekio duomenis.

3. Žymūs hidrologai Smalininkų VMS duomenis vertina palankiai, išreikšdami abejonių tik dèl 1812-1827 m. laikotarpio nuotèkio ir minimalių debitų iki 1890 m., tačiau nepaisant to, duomenis naudoja savo tyrimuose.

4. Nuo daugiamečio vidurkio reikšmingai $(\alpha=0,05)$ nutolę 1850-1962 ir 1963-2009 m. laikotarpių vidutinio metinio nuotèkio vidurkiai, o 1963-2009 m. laikotarpio Nemuno nuotèkis labiausiai paveiktas žmogaus veiklos.

5. Pagal Smalininkų VMS vidutinio metinio nuotèkio duomenis 1961-1990 m. standartinè norma yra 5\% mažesnè už daugiametę.

6. Nemuno ties Smalininkais ilgalaikiai duomenys labai vertingi mokslui ir praktikai, nes jie igalina pagrịstai nagrinèti vietines, regionines ir net pasaulines - klimato-nuotékio problemas.

Gauta 20100803 Priimta 20110117

\section{Literatūra}

1. Gailiušis B., Jablonskis J., Kovalenkovienè M. Lietuvos upés. Hidrografija ir nuotékis. Kaunas, 2001. 792 p.

2. Gedgaudas Č. Mūsu praeities beieškant. Kaunas: Aušra, 1994. 359 p.

3. Kolupaila S. Nemuno tyrinejjimų istorijos bruožai. Židinys. 1934. Nr. 7. P. 51-64.

4. Materialy dlya geografii i statistiki Rossii. Sanktpeterburg, $1861.746 \mathrm{p}$.

5. Sirokomlè V. Nemunas nuo versmiu iki žiočių. Vilnius, 1991. $82 \mathrm{p}$.

6. Lasinskas M. Lietuvos upiu nuotékio tyrimai. Bibliografija. Kaunas, 1994. 152 p.

7. Kholshevnikov V. N. Neman. Kostroma, 1902. 80 p.

8. Merching G. K. Proyektnyye predlozheniya ob elektrogidravlicheskom kaptazhe r Nemana u m. Birshtan i m. Nemanyun. Tr. Komissii po elektrogidravlicheskoy opisi vodnykh sil Rossii. Petrograd, 1911. Vyp. 1. P. 171-177.

9. Kolupaila S. Nemuno kilpa. Kosmos. 1929. Nr. 5. P. 169200.

10. Smilgevičius J. Nemuno hidroelektros stotis ties Pažaisliu. Kaunas, 1934. 34 p.

11. Burneikis J. Ar statysime Birštono HE? Mokslas ir gyvenimas. 1983. Nr. 9. P. 10-11.

12. Aut. kol. Kruonio HAE didybe ir vargai. Vilnius, 1999. 200 p.

13. Jablonskis J., Lasinskas M. Nemuno-Dniepro sujungimas. Mokslas ir technika. 1962. Nr. 2. P. 9-11.

14. Macevičius J. Lietuvos TSR upių tyrimai ir artimiausi uždaviniai. Geografinis metraštis. 1959. T. 2. P. 29-51.

15. Lietuvos hidrometeorologijos istorija. Hidrometeorologijos straipsniai. Vilnius, 1992. T. 15.320 p.
16. Resursy poverkhnostnykh vod SSSR. Gidrologicheskaya izuchennost. Leningrad, 1963. T. 4. Vyp. 3. 172 p.

17. Kolupaila S. Hidrometrinis metraštis II. Kaunas, 1930. $376 \mathrm{p}$.

18. Hidrologijos metraštis 2008. Vilnius, 2009. 206 p.

19. Kolupaila S. Nemuno nuotakis per 121 metus (1812-1932). Kosmos. 1932. Nr. 7-12. P. 317-323.

20. Gimbutas I., Danys J. V. Steponas Kolupaila. Čikaga, 1974. $464 \mathrm{p}$.

21. Macevičius J. Steponas Kolupaila (1892-1964). Hidrometeorologijos straipsniai. Vilnius, 1992. T. 15. P. 177-198.

22. Kolupaila S. Nemunas. Kaunas, 1940. 220 p.

23. Kolupaila S. Bibliography of Hydrometry. Notre Dame, 1961.975 p.

24. Kolupaila S. Hidrometrija. T. I, II. Kaunas, 1939. 396 p.; 1940. 474 p.

25. Gaigalas G. Vandens matavimo stočių tinklo raida. Žemetvarka ir hidrotechnika. 2004. T. 4. P. 21-24.

26. Kolupailo S. I. Uchet stoka r. Nemana za 1812-1932 gody. IV Gidrologicheskaya konferentsiya Baltiyskikh stran. Leningrad, 1933. $17 \mathrm{p}$.

27. Lasinskas M. Nemuno nuotèkis ties Smalininkais. Hidrometeorologijos straipsniai. 1970. T. 3. P. 5-17.

28. Lasinskas M. I. Issledovaniye zakonomernostey rezhima stoka r. Nyamunas. Avtoref. dis. ... d-ra geogr. nauk. KaunasVilnius, 1972. $41 \mathrm{p}$.

29. Yablonskis Y. S. Vekovaya ciklichnost gidrometeorologicheskikh elementov yuzhno-pribaltiyskoy chasti SSSR. Tr. AN Lit. SSR. Ser. B. 1971. T. 2(65). P. 115-130.

30. Gidrologicheskiy ezhegodnik 1950 g. Leningrad, 1956. T. 1. Vyp. 4-6. 416 p.

31. Resursy poverkhnostnykh vod SSSR. Leningrad, 1965. T. 4. Vyp. 3. $251 \mathrm{p}$.

32. Lasinskas M., Burneikis J. Lietuvos TSR upiu kadastras (Nemuno nuotékis). Vilnius, 1960. II d. 206 p.

33. Šostakovič V. B. Nemuno režimo periodiški svyravimai. Kosmos. 1934. Nr. 7-12. P. 177-184.

34. Jablonskis J. Nemuno nuotekis per 180 metų. Energetika. 1994. Nr. 4. P. 19-32.

35. Macevičius J. Lietuvos upių metinio nuotèkio periodiniai svyravimai. Geografinis metraštis. 1959. T. 2. P. 161-170.

36. Lasinskas M., Burneikis Yu. Stok reki Nyamunas (Neman). Kaunas, 1961. 197 p.

37. Jablonskis J. Lietuvos upių nuotekio cikliniai svyravimai. Energetika. 1992. Nr. 4. P. 16-37.

38. Kriaučiūnienè J., Meilutytė-Barauskienè D., Rimkus E., Kažys J., Vincevičius A. Climate change impact on hydrological processes in Nemunas River basin. Baltica. 2008. Vol. 21. No. 1-2. P. 51-61.

39. Meilutytè-Barauskienè D. Klimato kaitos itaka Lietuvos upių nuotèkiui. Daktaro disertacija. Kaunas, 2009. 125 p. 
Jonas Jablonskis, Mykolas Lasinskas

THE 200th ANNIVERSARY OF STATIONARY HYDROMETRIC INVESTIGATIONS OF THE RIVER NEMUNAS

Sum mary

The river Nemunas is one of the largest and best investigated rivers of Lithuania and the Baltic region. The first observations of its water level were started in the river's lower reaches - in the small towns Rusnè, Sèliai, Tilžè and Smalininkai in the begining of the 19th century by Prussian institutions.

The 200th aniversary of the Smalininkai water gauging station (situated $111 \mathrm{~km}$ from the mouth of the river Nemunas), in which the water level and ice were observed, will be celebrated on 1 October 2011. The water level and runoff are measured till now. The purpose of investigating the river Nemunas and the reliability of accumulated data are discussed; also, fluctuations of the runoff and trends for the period 1812-2009 are presented. While compiling and arranging the hydrometric data of the Smalininkai water gauging station, a lot of work was performed by the famous Lithuanian hydrologist Steponas Kolupaila.

Key words: the Nemunas, water gauging station, water level, runoff, runoff fluctuations

\section{Йонас Яблонскис, Миколас Ласинскас}

\section{0-ЛЕТИЕ СТАЦИОНАРНЫХ ГИДРОМЕТРИЧЕ- СКИХ ИССЛЕДОВАНИЙ РЕКИ НЯМУНАС}

Резюме

Нямунас является наиболее гидрометрически изученной рекой Литвы и Прибалтийского региона. Наблюдения за уровнем воды и ледовыми явлениями в низовьях реки - в поселках Русне, Селяй, Тильже и Смалининкай осуществлялись с начала XIX в. учреждениями Пруссии.

1 октября 2011 г. исполнится 200 лет с начала гидрометрических наблюдений на водомерной станции Смалининкай, которая расположена в 111 км от устья реки Нямунас (р. Атмата). В статье рассмотрены исторические условия необходимости изучения гидрологического режима реки, достоверность стоковых характеристик, колебания и измерения стока за 18122009 гг. Отмечается значимость работ по расчету стока реки за 1812-1932 гг. известного литовского гидролога Стяпонаса Колупайлы.

Ключевые слова: Нямунас, водомерная станция, уровень воды реки, сток реки, изменение стока 